\title{
Self-Determination and Regional Human Rights Bodies: The Case of Southern Cameroons and the African Commission on Human and Peoples' Rights
}

\author{
Brianne McGonigle Leyh
}

\section{Introduction}

In accordance with international law, all peoples have the right to selfdetermination. The right to self-determination is generally seen as the right to freely decide upon and pursue political, economic, social and cultural development. It is embodied in the UN Charter and, importantly, in binding international and regional human rights documents. Asserting or proclaiming this right, however, is never straightforward given the indeterminate, controversial and politically sensitive nature of the right. ${ }^{1}$ Indeed, these characteristics of the right to self-determination are arguably symptomatic of the problems with international law, more generally.

Contentious issues concerning claims of self-determination continuously arise, often together with violence and even war. Increasingly, groups asserting their right to self-determination are looking to international human rights institutions to pronounce upon or clarify this right. And, while many human rights institutions regularly contribute to norm specification, with regard to self-determination claims, international human rights institutions often shy away from considering these claims or fail to address them directly. This hands-off approach may originate from a fear that the institutions may contribute to further confusion or a fear of losing legitimacy amongst states whose support they rely upon to operate. Rather than applauding groups seeking solutions through non-violent legal processes, and providing much needed interpretation of the right, human rights institutions often leave groups asserting self-determination claims with little to no guidance on what the right entails and how it can effectively be claimed and enforced. This reluctance on the part of human rights institutions reflects a major problem with international law, namely its inability to help protect human rights.

1 J. Klabbers, "The Right to be Taken Seriously: Self-determination in International Law" (2006) 28 Human Rights Quarterly 186; A. Cassese, A Self-determination of Peoples: A Legal Reappraisal (Cambridge University Press, Cambridge: 1996) 22. 
Under the existing framework of self-determination, such actions may even encourage resort to conflict and violence.

This article will examine the right to self-determination in human rights law through exploration of the case of the Southern Cameroons and their claims before the African Commission on Human and Peoples' Rights (ACmHPR). The situation of the Southern Cameroons is linked to its colonial history, where the predominantly Anglophone region was joined and later subsumed within the larger and more dominant Francophone Republic of Cameroon (RoC). The Southern Cameroonians have long asserted, through non-violent means, their right to self-determination in order to ensure their social, cultural, economic and political rights. These claims have been based on three main theories. The first two of these are based on the legal and historical view that the RoC illegally annexed the territory of Southern Cameroons. ${ }^{2}$ The two illegal annexation theories argue that the RoC is illegally occupying the Southern Cameroons territory, which was a separate (if not a sovereign) entity under international law before 1961 under the terms of the UN Trusteeship Agreement. ${ }^{3}$ One theory is based on the argument that the $\mathrm{RoC}$ under the 1961 Constitution was illegal from the start, as it failed to create the federal union endorsed by the 1961 plebiscite and UN General Assembly Resolution $1608 .{ }^{4}$ The other theory is based on the argument that the RoC illegally annexed the Southern Cameroons when it dissolved the federal structure in 1972 and replaced it with the Unified Republic of Cameroon under a new non-federal constitution. ${ }^{5}$

The third theory derives from the fundamental rights guaranteed under the African Charter. This theory argues that the Southern Cameroonians are a people and, as such, are guaranteed the right to self-determination and freedom from

2 Southern Cameroons v. Attorney General of the Federal Republic of Nigeria, Affidavit in Support para. 37, Suit No. FHC/ABJ/CS/30/2002, Federal High Court of Nigeria Holden at Abuja, available at $<$ http://southerncameroonsig.typepad.com/abuja.pdf $>$. See also, "The Legal Argument for Southern Cameroons Independence," Southern Cameroons Workshop in Bamenda, 11 February 2005, available at <southerncameroonsig.org/.../legal_argument_for_southern _cameroons.pdf>.

3 Ibid., 37 .

4 This argument is outlined in more detail in "The Legal Argument for Southern Cameroons Independence," produced at the Southern Cameroons Workshop in Bamenda, 11 February 2005, available at <http://www.southerncameroonsig.org/files/legal_argument_for_southern _cameroons.pdf $>$.

5 This was the primary argument advanced in the 1993 Buea Declaration. Declaration by the Anglophone Congress assembled at Buea on 2 and 3 April 1993 (Buea Declaration) available at $<$ http://www.southerncameroonsig.org/files/southern_cameroonsbuea_anglophone_congress _1993.pdf >. 
oppression of another people under Articles 19 and 20 of the African Charter. ${ }^{6}$ Further, it suggests that the RoC systematically violates a litany of individual rights guaranteed under human rights law generally and the African Charter specifically, which supports the argument for a right to self-determination. ${ }^{7}$ This article focuses on this third theory argued before the ACmHPR.

The first part of this article will touch upon the right to self-determination and its controversial place in international law. The next section will detail the case of the Southern Cameroons and evaluate and critique the ACmHPR's approach. The approach taken by the Commission failed to clarify the right as well as the relationship between recognizing individual rights, on the one hand, and maintaining state sovereignty, on the other hand. Its decision highlighted the vulnerable position of human rights institutions and underscored the fact that they are, in many ways, inherently weak. The final section looks at the role of human rights bodies, focusing on protection and norm development. If decisions from human rights bodies are to help contribute to human rights protection and the strengthening of international law, more must be done by these institutions to reinforce their positions and by the broader international community to bolster and support their decisions. The article calls for strengthening human rights institutions and their ability to facilitate peaceful resolution of disputes, which in turn can help address (albeit modestly) some problems with international law. International human rights mechanisms have an important role to play not only when it comes to norm specification but, more importantly, when it comes to conflict prevention.

\section{Self-Determination under International Law}

The right to self-determination in international law originates from the right of colonized people to achieve independence from foreign colonial rule. ${ }^{8}$ The exercise of the right to self-determination has provided the basis for the

6 The Banjul Communiqué, 37th Session of the African Commission on Human and Peoples' Rights (ACHPR) Re: Communication No. 266/2003, available at <http://www.unpo.org/content /view/2534/145/>.

7 Declaration by the Anglophone Congress assembled at Buea on the 2nd and 3 rd of April 1993 (Buea Declaration), available at <http://www.southerncameroonsig.org/files/southern _cameroonsbuea_anglophone_congress_1993.pdf>; The Banjul Communiqué, 37th Session of the African Commission on Human and Peoples' Rights (ACHPR) Re: Communication No. 266/2003, available at <http://www.unpo.org/content/view/2534/145/>.

8 H. Hannum, Autonomy, Sovereignty and Self-determination:The Accommodation of Conflicting Rights (University of Pennsylvania Press, Pennsylvania: 1996) 27. 
independence of peoples from colonial domination, resulting in the creation of more than 80 new states. ${ }^{9}$ However, the right has since expanded from its original application, and today it arguably applies outside of the colonial context.

Seen as the right of a people to "freely determine their political status and freely pursue their economic, social and cultural development,"10 selfdetermination is often viewed as an indeterminate and controversial norm in international law. ${ }^{11}$ There are many reasons for its controversial status, including the fact that there is little clarity about how to determine when the right is applicable. Moreover, there are obvious clashes with the principle of the territorial integrity of states, which renders the right politically sensitive. Territorial integrity is the preservation of the territorial structure of the state, ${ }^{12}$ and there is a preference in the international community for the preservation of existing state boundaries. Notwithstanding this preference, however, the right to selfdetermination is reinforced not only in international law more generally but human rights instruments specifically.

Since the end of the Second World War, a series of international instruments have recognized self-determination as a fundamental principle of international law. ${ }^{13}$ Article $1(2)$ of the UN Charter refers to the "principle of equal

The United Nations and Decolonization available at <http://www.un.org/en/decolonization>.

10 General Assembly Resolution 1514, "Declaration on the Granting of Independence to Colonial Countries and Peoples" (1961) UN Doc.A/4684 para. 2 available at <http://www .un.org/documents/ga/res/15/ares15.htm>.

11 Klabbers, note 1 at 186, 206; Cassese, note 1 at 22.

12 J. Crawford, The Creation of States in International Law 2nd (Oxford University Press, Oxford: 2006) 118-120. For example, the 1993 Vienna Declaration on Human Rights and the Declaration on Principles of International Law, which notes the significance of selfdetermination as a legal right, equally emphasizes the importance for preserving the territorial integrity of states. In: United Nations World Conference on Human Rights, Vienna Declaration and Programme of Action (1993); Declaration On Principles Of International Law Concerning Friendly Relations And Co-operation Among States In Accordance With The Charter of The United Nations, Annex, principle 5 (24 October 1970) available at <http://www.hku.edu/law/conlawhk/conlaw/outline/Outline4/2625.htm>.

13 See for example Charter of the United Nations Art. 1(2) (1945), available at <http://www .un.org/en/documents/charter/index.shtml>;General Assembly Resolution 1514, Declaration on the Granting of Independence to Colonial Countries and Peoples, Art. 2, UN Doc. A/4684 (1961), available at <http://www.un.org/documents/ga/res/15/ares15.htm>; General Assembly Resolution 2200A, International Covenant on Civil and Political Rights (1966) 999 UNTS 171, Art. 1 available at <www2.ohchr.org/english/law/ccpr.htm>. Art. 1 was referred to in Legal Consequences of the Construction of a Wall in the Occupied Palestinian Territory, Advisory Opinion, 2004 ICJ 171-2, para. 88 (9 July 2004), available at 
rights and self-determination of peoples." ${ }^{14}$ Additionally, Articles 55 and 56 declare that all UN Member States pledge to uphold the principle of selfdetermination. ${ }^{15}$ Paragraph 2 of the UN General Assembly Declaration on the Granting of Independence to Colonial Countries and Peoples recognizes the right, ${ }^{16}$ and the Declaration on Principles of International Law Concerning Friendly Relations and Co-operation Among States (Declaration on Friendly Relations) also affirms the right of colonized people to form independent sovereign nations. ${ }^{17}$ Moreover, common Article 1(1) from the International Covenant on Civil and Political Rights (ICCPR) and the International Covenant on Economic, Social and Cultural Rights (ICESCR) includes the right of all people to "freely determine their political status and freely pursue their economic, social, and cultural development."18 The Human Rights Committee, the human rights body monitoring the implementation of the ICCPR, has further found that peoples have the right to choose their own form of constitution or government and are to freely determine their political status ${ }^{19}$ even outside of the colonial context. ${ }^{20}$

Regional instruments have also recognized this important right. Most importantly for this article, Article 19 of the African Charter on Human and Peoples Rights (African Charter) provides that "All peoples shall be equal; they shall enjoy the same respect and shall have the same rights. Nothing shall justify the

<http://www.ICJ-cij.org/docket/files/131/1671.pdf>. It also appears in other international or regional instruments. See, e.g. Organization of African Unity (OAU), African Charter on Human and Peoples' Rights (“Banjul Charter”), 27 June 1981, CAB/LEG/67/3 rev. 5, 21 I.L.M. 58 (1982), available at: <http://www.refworld.org/docid/3ae6b363o.html >. Art. 20.

14 Charter of the United Nations Art. 1(2) (1945), available at <http://www.un.org/en/documents /charter/index.shtml>; see also Art. 55 .

15 See also Western Sahara (Advisory Opinion), 1975 ICJ 54 (16 October 1975), available at $<$ http://www.ICJ-cij.org/docket/files/61/6195.pdf>. Northern Cameroons (Cameroon v. U.K.), 1963 ICJ 21 (2 December 1963), available at <http://www.ICJ-cij.org/docket/ files/48/5207.pdf $>$.

16 General Assembly Declaration on the Granting of Independence to Colonial Countries and Peoples UN Doc. A/RES/1514(XV) (14 December 1960).

17 General Assembly Declaration 2103 (XX) UN Doc. A/RES/2103 (20 December 1965).

18 International Covenant on Civil and Political Rights Art. I (1966) available at <http:// www2.ohchr.org/english/law/ccpr.htm>; General Assembly "International Covenant on Economic, Social and Cultural Rights” UN Doc. A/6316, 3 Jan 1966; See also P. Williams \& F. Pecci, "Earned Sovereignty: Bridging the Gap between Sovereignty and Selfdetermination" (2004) Stanford Journal of International Law 2-3.

19 Human Rights Committee, General Comment No. 25, adopted on 12 July 1996, para. 2.

20 Human Rights Committee, Concluding Observations on Azerbaijan, UN Doc. A/49/40, 3 August 1994 . 
domination of a people by another." In addition, Article 20 of the African Charter states, in part, that all peoples have the "unquestionable and inalienable right to self-determination."21 The African Charter is notable for the fact that unlike other regional human rights conventions, like the European or American Conventions, it recognizes peoples' rights or group rights.

Thus, self-determination is not merely a general right from colonial or foreign domination, but has expanded to include political, economic, social and cultural rights within a state. Moreover, the right to self-determination, as described by the ICCPR, HRC and UN resolutions, extends to all groups of people who share a common heritage, language, geographic area and culture. ${ }^{22} \mathrm{As}$ such, self-determination is a right that is held collectively by a "people."23

\section{Internal and External Self-Determination}

Self-determination has both an internal and external dimension. ${ }^{24}$ Internal self-determination is a "people's pursuit of its political, economic, social and cultural development within the framework of an existing state."25 The principle of internal self-determination affords a group of people within a state the right to determine its own political destiny (and to remain free from state persecution) without seceding from the state. ${ }^{26}$ Internal self-determination could include devolution of power to autonomous regions within states or power sharing arrangements that give minority groups, for example, increased representation in national governments. ${ }^{27}$ Coalition governments at the national level, rotating state presidencies, and guaranteed proportional representation

$21 \quad$ Banjul Charter, note 13.

22 Williams \& Pecci, note 18 at $2-3$.

23 D. Raic, Statehood and the Law of Self-determination (Kluwer Law International, The Hague: 2002) 242; H. Gros Espiell, Special Rapporteur, The Right to Self-determination: Implementation of United Nations Resolutions (1980) UN Doc. E/CN.4/Sub.2/405/Rev.1, 9 para. 56 .

24 UN General Assembly Declaration on Principles of International Law Concerning Friendly Relations and Cooperation among States in accordance with the Charter of the United Nations, UN Doc. A/RES/2625(XXV) (24 October 1970).

25 Reference Re Secession of Quebec, Supreme Court of Canada, 1998 CanLII 793 (SCC), para. 126.

26 Williams \& Pecci, note 18 at 2-3.

27 C. Borgen, "Kosovo's Declaration of Independence: Self-determination, Secession and Recognition" (2008) American Society of International Law, available at <http://www.asil .org/insightso80229.cfm>. 
in the state legislature and other state institutions are some examples of internal power sharing agreements. ${ }^{28}$ Internal self-determination, then, is the right of peoples to a specified level of devolved self-governance and participation in the national government. ${ }^{29}$ The international community favors internal selfdetermination as a way to minimize conflict while maintaining the sovereignty and territorial integrity of the state. ${ }^{30}$

However, under limited and often controversial circumstances, a group of people within a state may assert a claim for external self-determination. ${ }^{31}$ When a state excludes a group of people from political participation and engages in gross human rights violations, the affected peoples may be able to assert a claim of external self-determination and secede from the state to form a new, independent state. ${ }^{32}$ A claim of external self-determination, then, may possibly arise when internal self-determination mechanisms fail due to state persecution and serious violence. ${ }^{33}$ Indeed, limited past state practice in Kosovo, East Timor, and Papua New Guinea, amongst others, demonstrates that a state's continuing commission of gross human rights violations against a minority group can support that group's claim for external self-determination through secession. ${ }^{34}$

The right to self-determination will now be examined further in light of the role played by human rights bodies, with specific emphasis on the ACmHPR and the situation of Southern Cameroons. Since the creation of the RoC in 1961, the Southern Cameroonians have continually asserted their right to selfdetermination, and have also argued that the $\mathrm{RoC}$ has historically discriminated against them by depriving them of political, economic, and educational opportunities. The Southern Cameroonians have also repeatedly reported instances of arbitrary arrest, torture, and violence against pro-independence protestors and political organizers. ${ }^{35}$

\footnotetext{
28 Hannum, note 8 at $117-118$.

29 Ibid., 117-118.

30 Borgen, note 27 .

31 Ibid.

32 J. Hooper \& P. Williams, "Earned Sovereignty: The Political Dimension" (2003) Denver Journal of International Law and Policy; These conditions were laid down in African Commission on Human and Peoples' Rights, Katangese Peoples' Congress v. Zaire (1995) No. $75 / 92$.

33 Borgen, note 27.

34 Williams \& Pecci, note 18 at $2-3$.

35 See for example, S. Simanowitz, "Death of Journalist Mars Cameroon 5oth Anniversary Independence Festivities" (May 2010) New Internationalist available at $<$ http://www .newint.org/features/web-exclusive/2010/05/26/whats-to-celebrate/>.
} 
Despite the discrimination and human rights violations, the Southern Cameroonians have, thus far, not resorted to violence. Instead, for the past fifty to sixty years, they have sought non-violent solutions. In accordance with this non-violent policy, the Southern Cameroonians have pursued their human rights claims and their right to self-determination through international and regional mechanisms, with very few tangible results.

\section{African Commission on Human and Peoples' Rights}

Southern Cameroonians, through the Southern Cameroon Peoples Organization (SCAPO) and the Southern Cameroons National Council (SCNC), petitioned the ACmHPR, claiming human rights violations and asserting self-determination claims in January $2003{ }^{36}$ The eighteen leaders of SCAPO and the SCNC filed a complaint on behalf of themselves and the people of the Southern Cameroons alleging numerous violations under Articles 1, 2, 3(1), 4, 5 , $6,7,9,10,11,14$, and $17(1)$ of the African Charter. ${ }^{37}$ The complaint emphasized violations of Article 4 (right to life and physical integrity of the person); Article 5 (prohibiting torture and other cruel, inhuman, and degrading treatment and punishment); Article 6 (prohibiting arbitrary arrests and detention); Article 7 (right to fair trial); and Articles 9-12 (rights to freedom of expression, association, assembly and movement). ${ }^{38}$

In addition to these individual rights, the complaint also alleged that the RoC violated the collective rights of the people of Southern Cameroons under Articles 19 (equality of peoples); 20 (right to self-determination of peoples and freedom from colonialism); 21 (peoples' right to economic freedom); 22 (right to economic, social and cultural development); 23(1) (right to peace and security); and 24 (right to a satisfactory environment) of the African Charter. ${ }^{39}$ In particular, they sought freedom from colonial oppression, namely the colonial

36 ACHPR, 26th Activity Report of the ACHPR, Annex IV - Communication Decided in the 45th Ordinary Session, 13-27 May 2009: 266/2003 Kevin Mgwanga Gumne et al/Cameroon, available at <http://southerncameroonsig.typepad.com/files/achpr-comm-266-2003.pdf >. The Banjul Communiqué, 37th Session of the African Commission on Human and Peoples' Rights (ACHPR) Re: Communication No. 266/2003, available at <http://www .unpo.org/content/view/2534/145/>. See also African Charter on Human and Peoples' Rights (1981) 1520 UNTS 217 Arts. 1-7, 9-11, 14, 17, 27 available at <http://www.achpr.org/ english/_info/charter_en.html>.

38 The Banjul Communiqué, 37th Session of the African Commission for Human and Peoples' Rights (ACHPR) Re: Communication No. 266/2003 available at $<$ http://www .unpo.org/content/view/2534/145/>.

Ibid. 
oppression of the RoC. ${ }^{40}$ They argued that the occupation and assertion of colonial power by the RoC over the territory of the Southern Cameroons violates Articles 19 and 20, which acknowledge the legitimacy of self-determination movements that utilize internationally recognized methods of political resistance. ${ }^{41}$

In May 2009, the ACmHPR decided on the complaint, finding that the RoC had violated a number of rights protected under the African Charter and that the Southern Cameroonians constituted "a people" under Article 20 of the Charter. ${ }^{42}$ However, the ACmHPR stopped short of ruling that the Southern Cameroonians qualified for the right of external self-determination..$^{43}$ Instead, the Commission stated that it cannot "condone or encourage secession, as a form of self-determination for the Southern Cameroons," ${ }^{44}$ reaffirming the sovereignty of the RoC. The Commission upheld the principle of territorial integrity and further stated that the African Charter cannot be invoked to threaten the sovereignty of a state party. ${ }^{45}$ It further noted that any recourse to internal self-determination "must take into account the popular will of the entire population, exercised through democratic means, such as by way of a referendum, or other means of creating national consensus" and that it cannot be imposed by the African Commission. ${ }^{46}$ Notwithstanding this position, the ACmHPR offered to facilitate negotiations towards "an amicable solution" for the Southern Cameroonians and the $\mathrm{RoC}$, and requested that the parties enter into a constructive dialogue. It also asked the parties to report back on implementation of its

40 Ibid.

41 Art. 19 guarantees the equality of all peoples and prohibits "the domination of one people by another." Art. 20 establishes "the right to existence" and guarantees "the unquestionable and inalienable right to self-determination," such that people can "freely determine their political status and...pursue their economic and social development according to the policy they have freely chosen." Art. 20 also provides that "Colonized or oppressed peoples shall have the right to free themselves from the bonds of domination by resorting to any means recognized by the international community" and that "all peoples shall have the right to the assistance of the States parties to the present Charter in their liberation struggle against foreign domination, be it political, economic or cultural." See African Charter on Human and Peoples' Rights, note 37, Arts. 19-20.

ACHPR, 26th Activity Report of the ACHPR, Annex IV - Communication Decided in the 45th Ordinary Session, May 13-27, 2009: 266/2003 Kevin Mgwanga Gumne et al/Cameroon paras.178,214, availableat<http://southerncameroonsig.typepad.com/files/achpr-comm-2662003.pdf >.

43 Ibid., para. 194.

44 Ibid., para. 190.

45 Ibid., para. 191.

$46 \quad$ Ibid., para. 199. 
recommendations within 180 days of the decision. ${ }^{47}$ However, that period passed without any ensuing negotiations. ${ }^{48}$

Because Cameroon has not ratified the Protocol to the African Charter on the Establishment of the African Court on Human and Peoples Rights (ACtHPR), no individuals or groups can petition the court and the ACmHPR has no procedure to implement its recommendations. ${ }^{49}$ The ACmHPR Secretariat can only send letters reminding state parties of their obligations under the Charter, but there is currently no mechanism to compel or encourage the RoC to comply with the Commission's recommendations. ${ }^{50}$

\section{Role of Human Rights Bodies: Protection and Norm Development}

International human rights bodies, both judicial and non-judicial, have contributed to norm development on human rights-related issues. Together with the protection of human rights, norm development and norm specification is arguably one of the major achievements of human rights bodies. Nevertheless, human rights bodies often shy away from fully considering and interpreting provisions, thereby failing to provide much needed clarity on complex and contentious issues. An example of this can be seen in the Human Rights Committee's restrictive application of Article 1 of the ICCPR, which states that "all peoples have the right to self-determination." The Committee has refused the possibility of individual complaints under the ICCPR's Optional Protocol on the grounds of alleged violations of this article. The Committee's grounds for this refusal are based on the collective nature of the right of self-determination in the Covenant, and the fact that the Optional Protocol procedure is limited to individuals who claim that their individual rights have been violated. ${ }^{51}$ It should be noted, however, that the Human Rights Committee has given a more liberal interpretation to Article 27 ICCPR which relates to the abilities of minorities to enjoy their own culture, to profess and practice their own religion, or to use

\footnotetext{
47 Ibid., para. 215 .

48 Global Conscience Initiative "After ACHPR Ruling: Cameroon Government Still Not Ready for Dialogue," available at <http://www.gcicameroon.org/achpr_rally.htm>.

ACHPR, "ACHPR Information Sheet No. 3: Communication Procedure" 9, available at <http://www.achpr.org/english/_info/communications_procedure_en.html>.

5o Ibid.

$5^{1}$ See $A D$ (on behalf of Mikmaq Tribal Society) v. Canada, Admissibility, Communication No 78/1980, UN Doc. CCPR/C/22/D/78/1980, IHRL 2528 (UNHRC 1984), 29 July 1984, Human Rights Committee (UNHRC).
} 
their own language. ${ }^{2}$ This could be considered to counter Article 1 limitations. However, the scope of Article 27 has not been extended to cover possible claims under Article 1, were they available for the individual.

The above observations are also clearly applicable in the situation with the ACmHPR and the issue of self-determination. In 1995, the ACmHPR considered the case of Katanga concerning the issue of external self-determination in a post-colonial context. In this case, the Katangese Peoples' Congress sought recognition as a liberation movement and argued for the right to external selfdetermination for Katanga, a region in Zaire. ${ }^{33}$ The ACmHPR had an opportunity with this case to address important issues related to human rights and self-determination. Instead, it dealt with the complaint in a brief and arbitrary way, offering only two significant contributions. First, was the notion that internal self-determination could be recognized in a wide variety of ways that do not conflict with the principle of territorial integrity, such as through regional or local self-government, federalism or confederation. Unfortunately, it did not elaborate further, leaving commentators to wonder under what circumstances such forms of internal self-determination should be set up. Second, it noted that external self-determination would need evidence that Katangese people are denied the right to participate in government as guaranteed by Article 13(1) of the African Charter, as well as evidence of massive or serious violations of human rights. ${ }^{54}$

Later when the Southern Cameroons case came before it, the Commission again had the opportunity to provide crucial clarification and to elaborate on Katanga. Instead, the Commission further confused the issue of self-determination, equating the standard it laid out for external self-determination in Katanga with internal self-determination in the Southern Cameroons, essentially finding that massive violations of human rights is a precondition for any sort of internal self-determination. And while the people of Southern Cameroons have experienced continuous human rights violations it is arguable whether they have suffered serious or massive violations to the extent required by the Commission. Therefore, while it did go so far as to call the Southern Cameroonians a "people" it failed to elucidate on whether internal or external self-determination was justified under the circumstances. It failed to go into the differences between internal or external self-determination at all, despite

52 See UN Human Rights Committee (UNHRC), CCPR General Comment No. 23: Article 27 (Rights of Minorities), 8 April 1994, CCPR/C/21/Rev.1/Add.5 (para. 7), available at <http:// www.refworld.org/docid/453883fco.html>.

53 Katangese Peoples' Congress $v$. Zaire, note 32.

54 Ibid., para. 6. 
its previous (though brief) recognition of the scales of self-determination in Katanga. The result is that a standard set for external self-determination, namely massive human rights violations, now seems to be required for any sort of internal self-determination.

Such a high standard to meet for internal self-determination not only seems misplaced, but it could also be considered reckless. Such a position could potentially encourage non-violent groups, like the Southern Cameroonians, to take a more belligerent or aggressive position vis-à-vis the government. Therefore, despite the fact that "creating and implementing [...] rules in international law for partition and secession has significant potential to reduce the risk of conflict at relatively low cost," ${ }^{55}$ the Commission failed to provide much needed clarity and guidance that would help towards conflict prevention. And while this was an opportunity lost for the Commission, it is perhaps a feature of international law more generally, namely problems with clarifying rights. As noted by Buchanan, "international law [...] fails to provide coherent conceptual and institutional support for forms of self-determination short of full independence and for a principled way of ascertaining when more limited modes of self-determination are appropriate. ${ }^{56}$ Moreover, the ACmHPR made internal self-determination practically unavailable to peoples who are minorities in a state by requiring that any form of internal self-determination "must take into account the popular will of the entire population, exercised through democratic means." 57 This stance greatly limits the opportunities for minorities to realize any form of internal self-determination that is remotely at odds with a majority population. The example of the Southern Cameroons highlights the often lackluster role played by the ACmHPR when it comes to norm development and norm specification and it could be suggested that this is far from satisfactory where important rights and liberties of a people are at stake.

Finally, in terms of the protection of the human rights of those filing the complaint, the requests made to the respondent state to stop discriminatory practices and engage in a dialogue were weak and the RoC has unsurprisingly dismissed them. The inability to enforce or even effectively monitor follow up to recommendations is a serious weakness of the Commission specifically and human rights bodies more generally. It also touches on a fundamental problem

55 N. Richardson, "Breaking Up Doesn't Have to be So Hard: Default Rules for Partition and Secession" (2009) 9 Chicago Journal of International Law 685-716.

56 A. Buchanan, Justice, Legitimacy and Self-determination (Oxford University Press, Oxford: 2003) 331.

57 S. Weldehaimanot, "The ACHPR in the Case of Southern Cameroons" (2012) 9 SUR International Journal on Human Rights emphasis added. 
of international law: the inability to enforce or encourage compliance with decisions from human rights bodies.

\section{Conclusion}

Issues of self-determination are wide ranging and as noted by Klabbers they largely stem from the indeterminate, controversial and politically sensitive nature of the right. ${ }^{58}$ When international courts and quasi-judicial bodies have the opportunity to address the right, many are hopeful that they will help address some well-known problems associated with international law, such as ambiguity, inability to protect rights and lack of enforcement. In the situation of the Southern Cameroons, the Commission missed an opportunity to address these shortcomings. Moreover, it also failed to fulfill its role as a strong, regional human rights body. While the role of human rights adjudicatory bodies is debated, ${ }^{59}$ this article argues that the ACmHPR, as well as other human rights bodies, should strive to advance international law by contributing to human rights protection, norm development, norm specification and above all conflict prevention. Indeed, it is one of their most important tasks and is particularly relevant when dealing with claims of self-determination and systematic violations of human rights. They are in positions in which they can provide a principled approach of ascertaining when morelimited modes of self-determination are appropriate. Such a role could help stem future conflict. As such, their decisions should try to make remedies for violations more specific and, where possible, be followed-up more robustly. Instead, when these institutions shy away from or further confuse the matter the world community is reminded of the relative weakness of international law and its institutions.

$5^{8} \quad$ Klabbers, note 1; Cassese, note 1 at 22.

59 See J. Cavallaro and S.E. Brewer, "Re-evaluating Regional Human Rights Litigation in the Twenty-first Century: The Case of the Inter-American Court" (2008) 102 American Journal of International Law $768-770$. 